INFORMAATIOTUTKIMUKSEN PÄIVÄT 2020

\title{
Mikroyritysten sosiaalisen median kanavat
}

\author{
Markus Rytinki \\ Oulun yliopisto \\ markus.rytinki@oulu.fi \\ https://orcid.org/0000-0003-0534-8930
}

Katariina Ala-Rämi

Riitta Forsten-Astikainen

Heli Kurikkala

Santeri Halonen

Asiasanat: mikroyritykset, sosiaalinen media, kyselytutkimus

Tutkimuksessa kartoitetaan mikroyritysten sosiaalisen median käyttöä. Tavoitteena oli selvittää,

1. Mitä sosiaalisen median kanavia mikroyritykset käyttävät ja

2. Mihin tarkoitukseen viestintäkanavia käytetään mikroyrityksissä.

Artikkeli on lisensoitu Creative Commons Nimeä-EiKaupallinen-JaaSamoin 4.o Kansainvälinen -lisenssillä Pysyvä osoite: https://doi.org/10.23978/inf. 99139 
Lisäksi tutkimuksessa kartoitettiin mikroyritysten suosituimpia sosiaalisen median kanavia, yritysten viestintäsuunnitelman ja nettisivujen yleisyyttä, sosiaalisen median käytön kokonaistilannetta itsearviointina sekä aihepiiriin liittyviä kehityskohteita mikroyrityksissä.

\section{Tausta}

Tilastokeskus ja Eurostat tutkivat vuosittain yritysten sosiaalisen median käyttöä. Mikroyrityksiä ei kuitenkaan huomioida kummankaan organisaation tutkimuksissa. Tämä tutkimus täyttää tämän tiedollisen aukon Suomen osalta.

Eurooppalaisen määritelmän mukaan mikroyritys on riippumaton yritys, jonka palveluksessa on vähemmän kuin 10 työntekijää ja jonka vuosiliikevaihto on enintään 2 miljoonaa euroa tai taseen loppusumma enintään 2 miljoonaa euroa. Suomalaisista yrityksistä 93 prosenttia on mikroyrityksiä (265894 mikroyritystä, 323686 työntekijää). Yrittäjistä 68 prosenttia on mikroyrittäjiä. Koko yrityskentän liikevaihdosta mikroyritysten osuus on 16.6 prosenttia.

Sosiaalinen media sisältää erilaisia internet-pohjaisia sovelluksia (verkkoviestintäympäristöjä), joiden avulla käyttäjä voi luoda ja jakaa erilaisia sisältöjä. Sovelluksissa voi myös muodostaa uusia sosiaalisia verkostoja. Sosiaalisessa mediassa viestintä tapahtuu monelta monelle palveluntarjoajan välityksellä. Vuorovaikutteisuus, käyttäjälähtöisyys ja sosiaalisten suhteiden ylläpitäminen ovat somen keskeisiä piirteitä.

Tutkimus toteutettiin kyselytutkimuksena (Webropol). Aineistoa kerättiin sekä sähköisesti että jalkautumalla yritysten pariin. Kysely sisälsi 16 kysymystä, joista 6 oli avoimia kysymyksiä. Vastauksia saatiin yhteensä 60 kappaletta. Aineistoa kerättiin Pohjois-Pohjanmaan sekä Pohjois- ja Etelä-Savon mikroyrityksistä. Aineistonkeruussa hyödynnettiin Mikroyrittäjyyskeskus MicroENTREn (Kerttu Saalasti Instituutti, Oulun yliopisto) mikroyritysverkostoa.

Tutkimus luotaa ennen tutkimatonta mikroyritysten sosiaalisen median käyttöä monipuolisesti. Tutkimuksesta on hyötyä myös mikroyrittäjille itselleen, koska se kertoo suosituimmat sosiaalisen median kanavat toimialaluokittain ja sen, mihin tarkoitukseen mikroyritykset kanavia käyttävät. 